\title{
Modeling and Control for Smart Grid Integration of Solar/Wind Energy Conversion System
}

\author{
E. M. Natsheh, Member, IEEE, A. Albarbar, Member, IEE, and J. Yazdani, Member, IEEE
}

\begin{abstract}
Performance optimization, system reliability and operational efficiency are key characteristics of smart grid systems. In this paper a novel model of smart grid-connected PV/WT hybrid system is developed. It comprises photovoltaic array, wind turbine, asynchronous (induction) generator, controller and converters. The model is implemented using MATLAB/SIMULINK software package. Perturb and observe (P\&O) algorithm is used for maximizing the generated power based on maximum power point tracker (MPPT) implementation. The dynamic behavior of the proposed model is examined under different operating conditions. Solar irradiance, temperature and wind speed data is gathered from a grid connected, $28.8 \mathrm{~kW}$ solar power system located in central Manchester. Real-time measured parameters are used as inputs for the developed system. The proposed model and its control strategy offer a proper tool for smart grid performance optimization.
\end{abstract}

Index Terms-- Control systems, Hybrid power systems, MATLAB, Modeling, Photovoltaic systems, Power electronics, Smart grids, Wind power generation.

\section{INTRODUCTION}

$\mathrm{T}$ HE limitations of global resources of fossil and nuclear fuel, has necessitated an urgent search for alternative sources of energy. Therefore, a new way has to be found to balance the supply and demand without resorting to coal and gas fuelled generators. Smart grid is a system that would enable the integration of renewable energy sources and shift from reliance on fossil fuels, while maintaining the balance between supply and demand. The key characteristics of smart grid include [1]:

- Grid optimisation: system reliability and operational efficiency.

- Distributed generation: not only traditional large power stations, but also individual PV panels, micro-wind, etc.

- Advanced metering infrastructure (AMI): smart meters.

- Grid-scale storage.

- Demand response.

This work was supported in part by Manchester Metropolitan University School of Engineering and An-Najah National University Department of Computer Engineering.

E. M. Natsheh is with the School of Engineering, Manchester Metropolitan University, Manchester, UK (e-mail: emad.nat@gmail.com ).

A. Albarbar is with the School of Engineering, Manchester Metropolitan University, Manchester, UK (e-mail: a.albarbar@mmu.ac.uk ).

J. Yazdani is with the University of Central Lancashire, Preston, Lancashire, UK (e-mail: jyazdani@uclan.ac.uk ).
- Plug-in hybrid electric vehicles (PHEVs) and vehicle to grid (V2G).

This paper focuses mainly on the smart grid integration of PV/WT hybrid system (grid optimisation and distribution generation).

Over recent years several research and investment has been carried out in hybrid power system, such as Yang [2], who recommended an optimal design model for hybrid solar-wind system, which employs battery banks to calculate the system's optimum configurations in China. Dihrab [3], presented a hybrid solar-wind system as a renewable source of power generation for grid connected application in three cities in Iraq. Reichling [4], modeled a hybrid solar wind power plant in south western Minnesota for a two year period, using hourly solar irradiation and wind speed data. Ekren [5], showed an optimum sizing procedure of $\mathrm{PV} /$ wind hybrid system in Turkey. Several modeling studies on PV/WT power system have been conducted. Among them, Kim [6], developed a grid-connected photovoltaic model using PSCAD/EMTDC for electromagnetic transient analysis. Tsai [7], implemented an insulation-oriented PV model using MATLAB/SIMULINK software package. Gow [8], developed a general PV model which can be implemented on simulation platforms such as PSPICE or SABER. Khan [9], presented the model of a small wind-fuel cell hybrid energy system and analyzed life cycle of a wind-fuel cell integrated system. Chayawatto [10], developed a mathematical model of a dc/ac full-bridge switching converter with current control for PV gridconnected system under islanding phenomena; this phenomena occur when the grid system is disconnected for any reason and the distributed generation still supplies to any section of local loads. Onar [11], modeled a hybrid wind/FC/ ultra-capacitor (UC) power system for a grid-independent user with appropriate power flow controllers.

In this study, a detailed dynamic model, control and simulation of a smart grid-connected PV/WT hybrid power generation system is proposed. Modeling and simulation are implemented using MATLAB/SIMULINK and SimPowerSystems software packages to verify the effectiveness of the proposed system.

\section{SYSTEM DESCRIPTION AND MODELING}

Smart grid is a system consists of three layers: the physical power layer, the control layer and the application layer. And according to, Katherine Hamilton [1], smart grid has to be dynamic and have constant two-way communication, as 
shown in Fig.1. So, for example, with PV panels on the roofs, intelligent building system will generates, store and use their own energy. Hence, as active buildings they become part of the smart grid. This could save energy and increase reliability and transparency.

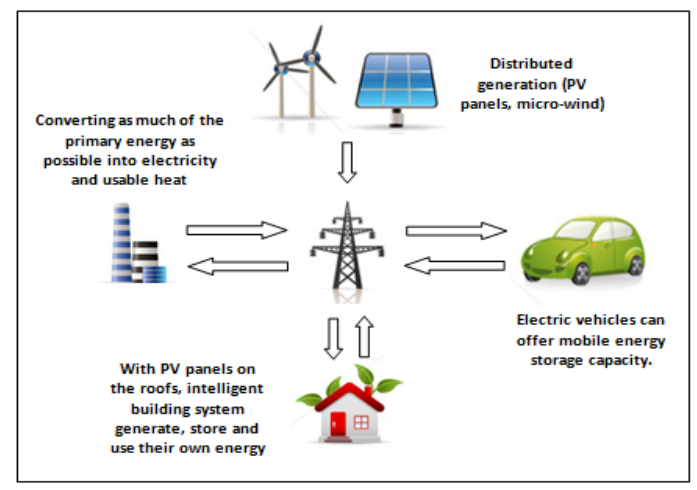

Fig. 1. General layout of the smart grid

In this section, the dynamic simulation model is described for photovoltaic/wind turbine hybrid generation system. The developed system consists of a photovoltaic array, dc/dc converter with an isolated transformer, designed for achieving the MPP with a current reference control $\left(I_{r e f}\right)$ produced by $\mathrm{P} \& \mathrm{O}$ algorithm, wind turbine, asynchronous induction generator, and ac/dc thyristor controlled double-bridge rectifier. The block diagram of the developed system is shown in Fig. 2.

\section{A. Modeling and Design of a Photovoltaic Module}

The general mathematical model for the solar cell has been studied over the past three decades [12]. The circuit of the solar cell model, which consists of a photocurrent, diode, parallel resistor (leakage current) and a series resistor; is shown in Fig. 3. According to both the PV cell circuit shown in Fig. 3 and Kirchhoff's circuit laws, the photovoltaic current can be presented as follows [13]:

$$
I_{p v}=I_{g c}-I_{o}\left[\exp \left(\frac{e v_{d}}{K F T_{c}}\right)-1\right]-\frac{v_{d}}{R_{p}}
$$

Where $I_{g c}$ is the light generated current, $I_{o}$ is the dark saturation current dependant on the cell temperature, $e$ is the

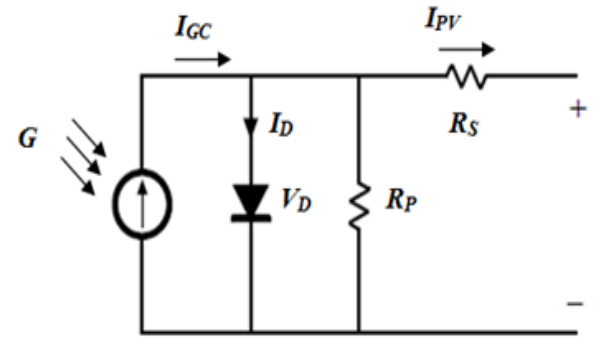

Fig. 3. Single diode PV cell equivalent circuit

electric charge $=1.6 \times 10^{-19}$ Coulombs, $K$ is Boltzmann's constant $=1.38 \times 10^{-23} \mathrm{~J} / \mathrm{K}, F$ is the cell idealizing factor, $T_{c}$ is the cell's absolute temperature, $v_{d}$ is the diode voltage, and $R_{p}$ is the parallel resistance. The photocurrent $\left(I_{g c}\right)$ mainly depends on the solar irradiation and cell temperature, which is described as [13]

$$
I_{g c}=\left[\mu_{s c}\left(T_{c}-T_{r}\right)+I_{s c}\right] G
$$

Where $\mu_{s c}$ is the temperature coefficient of the cell's short circuit current, $T_{r e f}$ is the cell's reference temperature, $I_{s c}$ is the cell's short circuit current at a $25^{\circ} \mathrm{C}$ and $1 \mathrm{~kW} / \mathrm{m}^{2}$, and $G$ is the solar irradiation in $\mathrm{kW} / \mathrm{m}^{2}$. Furthermore, the cell's saturation current $\left(I_{o}\right)$ varies with the cell temperature, which is described as [13]

$$
\begin{aligned}
I_{o} & =I_{o \alpha}\left(\frac{T_{c}}{T_{r}}\right)^{3} \exp ^{\left[\frac{e v_{g}}{K F}\left(\frac{1}{T_{r}}-\frac{1}{T_{c}}\right)\right]} \\
I_{o \alpha} & =\frac{I_{s c}}{\exp ^{\left(\frac{e v_{o c}}{K F T_{c}}\right)}}
\end{aligned}
$$

Where $I_{o \alpha}$ is the cell's reverse saturation current at a solar radiation and reference temperature, $V_{g}$ is the band-gap energy of the semiconductor used in the cell, and $V_{o c}$ is the cells open circuit voltage. In this study, a general PV model is built and implemented using MATLAB/SIMULINK to verify the nonlinear output characteristics for the PV module. The proposed model is implemented, as shown in Fig. 4. In this model, whereas the inputs are the solar irradiation and cell temperature, the outputs are the photovoltaic voltage and current. The PV models parameters are usually extracted from the manufactures data sheet.

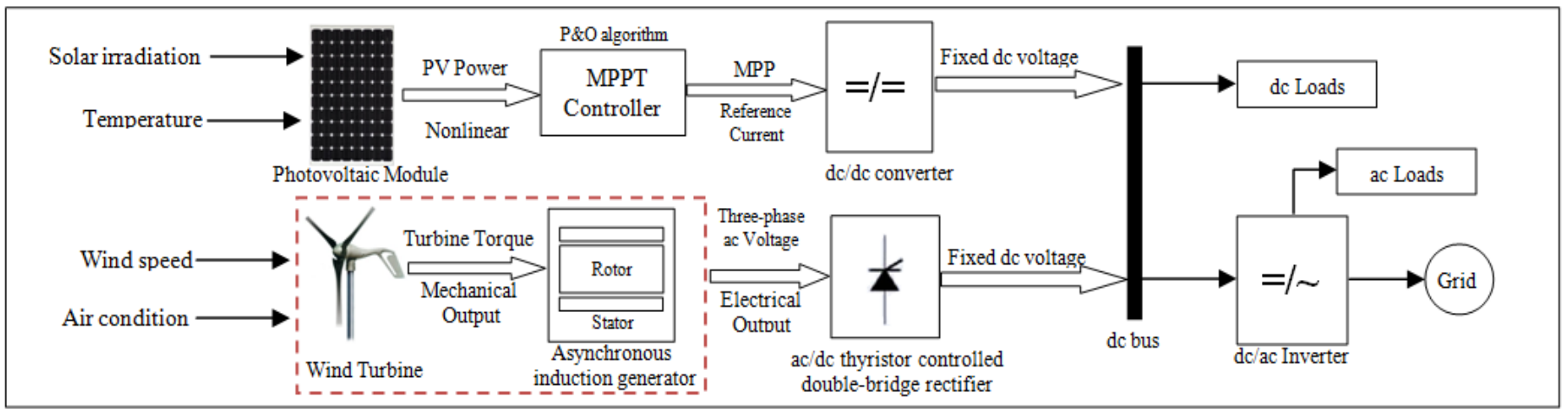

Fig. 2. Block diagram of the proposed system 


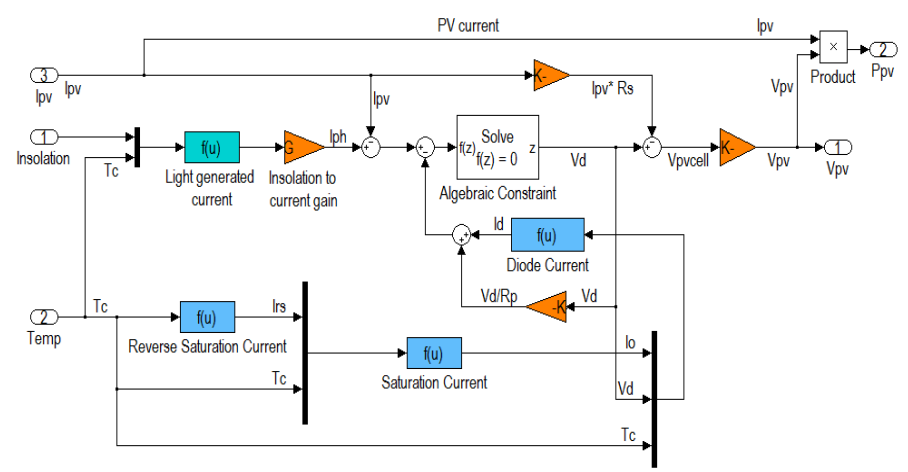

Fig. 4. Subsystem implementation of the PV model

\section{B. Modeling and Design of a WT and Induction Generator}

Several studies have been reported regarding to WT and wind generators [14]. In this study, the proposed WT model is based on the wind speed versus WT output power characteristics. The output power of the wind turbine is given by $[15]$ :

$$
P_{m}=c_{p}(\lambda, \beta) \frac{\rho A}{2} v_{\text {wind }}^{3}
$$

Where $P_{m}$ is the mechanical output power of the turbine, $c_{p}$ is the performance coefficient of the turbine, $\lambda$ is the tip speed ratio of the rotor blade, $\beta$ is the blade pitch angle, $\rho$ is the air density, $A$ is the turbine swept area, and $v_{\text {wind }}$ is the wind speed.

The performance coefficient model $c_{p}(\lambda, \beta)$ used in this paper is taken from [16] and given by:

$$
c_{p}(\lambda, \beta)=c_{1}\left(\frac{c_{2}}{\lambda_{i}}-c_{3} \beta-c_{4}\right) e^{\left(-c_{5} / \lambda_{i}\right)}+c_{6} \lambda
$$

Where constants $c_{1}$ to $c_{6}$ are parameters that depend on the wind turbine rotor and blade design, and $\lambda_{\mathrm{i}}$ is a parameter given in (7).

$$
\frac{1}{\lambda_{i}}=\frac{1}{\lambda+0.08 \beta}-\frac{0.035}{\beta^{3}+1}
$$

Furthermore, (5) can be normalized and simplified for specific values of $A$ and $\rho$, as in (8):

$$
P_{m-p u}=k_{p} c_{p-p u} v_{\text {wind }-p u}^{3}
$$

Where $P_{m-p u}$ is the power in per unit (p.u.) of nominal power for particular values of $\rho$ and $A, c_{p-p u}$ is the p.u. value of the performance coefficient $\mathrm{c}_{\mathrm{p}}, k_{p}$ is the power gain, $v_{\text {wind-pu }}$ is the p.u. value of the base wind speed. The based wind speed is the mean value of the expected wind speed in $(\mathrm{m} / \mathrm{s})$.

The modified model of the WT is implemented as shown in Fig. 5. In this model, whereas the inputs are the wind speed and generator speed, the output is the torque applied to the generator shaft. The torque of the generator is based on the generator power and speed.

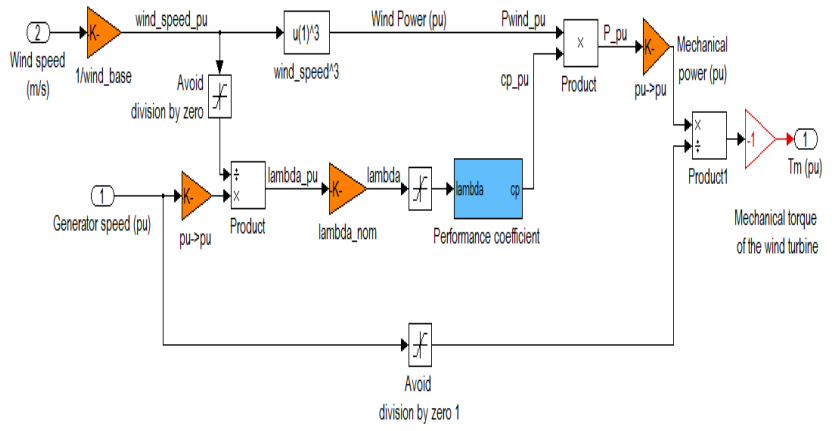

Fig. 5. Subsystem implementation of the WT model

The wind turbine induction generator (WTIG) model is designed using the built-in SimPowerSystem library. The rotor shaft is driven by the WT which produces the mechanical torque according to the generator and wind speed values. The electrical power output of the generator (stator winding) is connected to the smart grid.

\section{Power Control Systems}

\section{1) Photovoltaic Control System}

The output characteristics of the PV model with different solar irradiance and cell temperature are nonlinear. Furthermore, the solar irradiation is unpredictable, which makes the maximum power point (MPP) of the PV module changes continuously. Therefore, a maximum power point tracker (MPPT) technique is needed to operate the PV module at its maximum power point (MPP). Perturb and observe $(\mathrm{P} \& \mathrm{O})$ algorithm is the maximum power point tracker (MPPT) control algorithm that will be adapted in this model. The P\&O algorithm operates by periodically incrementing or decrementing the $\mathrm{PV}$ array operating current, and comparing the PV output power with the previous one. If it's positive the control system moves the PV array operating point in the same direction, otherwise, it's moved in the opposite direction.

A MPPT controller model is built and implemented using MATLAB, to operate the PV module at its maximum power point. The $\mathrm{P} \& \mathrm{O}$ algorithm requires two measurements: measurement of the current $\left(I_{p v}\right)$ and measurement of the voltage $\left(V_{p v}\right)$. The proposed model is implemented as shown in Fig. 6.

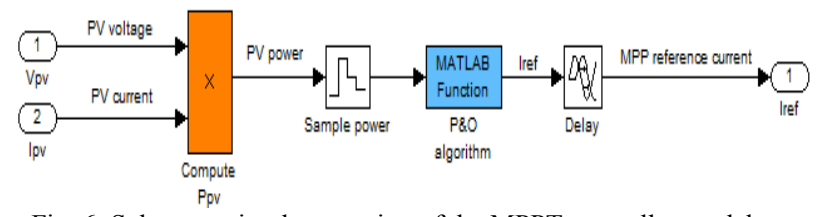

Fig. 6. Subsystem implementation of the MPPT controller model

In addition, a dc averaged switched model converter with input current control $\left(I_{r e f}\right)$ is built and implemented using MATLAB/SIMULINK, to reduce the switching harmonics and steps-up the photovoltaic voltage to a higher dc voltage (e.g. $400 \mathrm{~V}$ ). The proposed model is implemented as shown in Fig.7. 


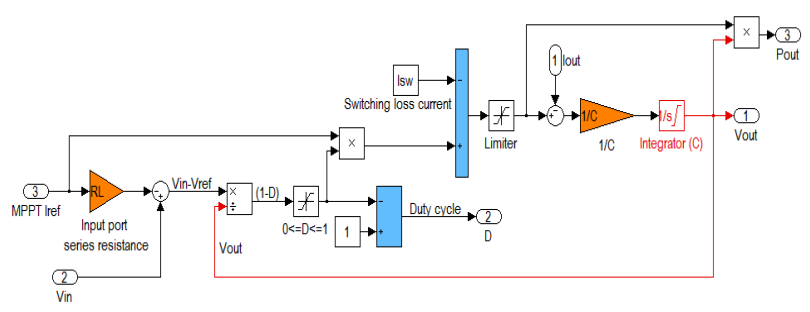

Fig. 7. Subsystem implementation of the dc/dc converter model

However, when the PV system with a MPPT is connected to the power electronic converters (PEC), an automatic feedback controller will be needed to balance the power and maintain the direct voltage constant; especially when the system is running under various conditions. The proposed PV control system model is implemented as shown in Fig. 8(a) and $8(\mathrm{~b})$.

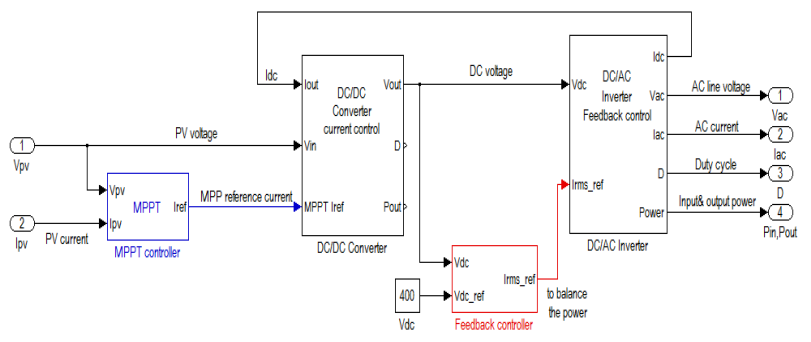

Fig. 8(a) Implementation of the PV control system model

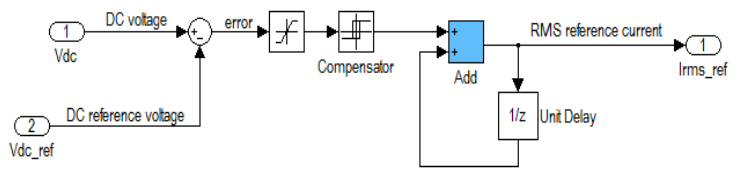

Fig. 8(b) Subsystem implementation of the feedback controller model

\section{2) Wind Turbine Control System}

Due to the variations in wind speed, the output power of the wind turbine induction generator experiences variations in frequency and amplitude. Therefore, a controllable ac/dc converter is used to smooth the wind turbine output power before being supplied to other electronic devices. Fig. 9, shows the schematic of the double-bridge rectifier.

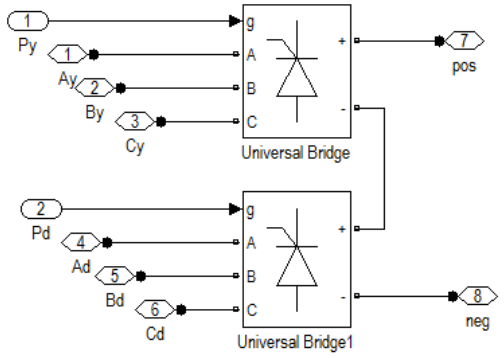

Fig. 9. The double-bridge rectifier

One of the advantages of the double-bridge rectifier is the controllable dc output voltage, by tuning the firing angle $(\alpha)$ of the 12-pulse synchronized PWM generator, and the narrowed commutation periods, which causes less harmonic distortion effects on the source side. In this model a three-phase twowinding transformer is used to obtain six input ports with appropriate phase angles for the double-bridge rectifier. The firing angle $(\alpha)$ is controlled by a discrete PI controller. The proposed WT control system model is implemented as shown in Fig. 10.

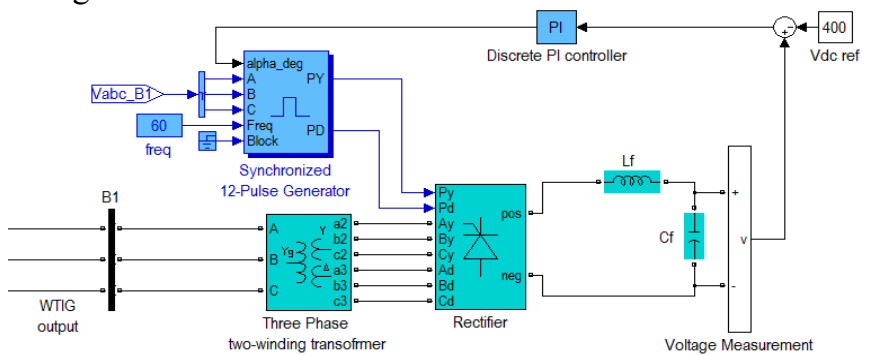

Fig. 10. The double-bridge rectifier, filters elements and control system model

\section{3) dc/ac inverter for load side}

An ac averaged switched model inverter is built and implemented using MATLAB/SIMULINK, to convert the direct current (dc) into alternating current (ac), at a switching frequency $\left(f_{s}\right)$ greater than the $\mathrm{AC}$ line frequency $(50 \mathrm{~Hz}-$ $60 \mathrm{~Hz}$ ). Losses are included due to output-port series resistance $\left(R_{O P}\right)$ and input-port switching loss current $\left(I_{I P}\right)$. The proposed model is implemented as shown in Fig. 11.

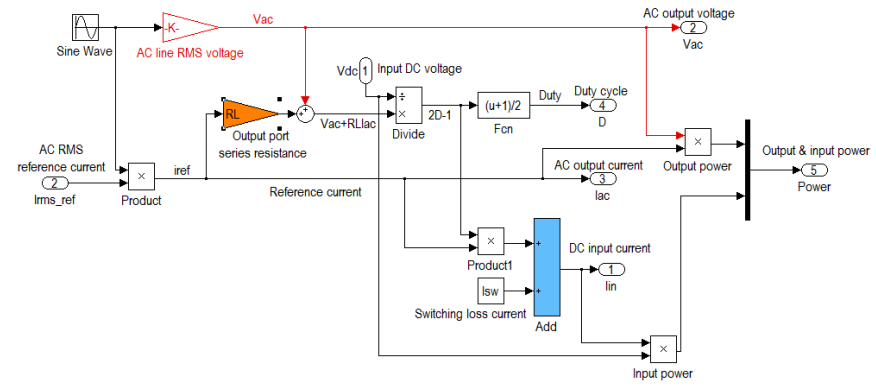

Fig. 11. Subsystem implementation of the dc/ac inverter model

\section{Simulation Results AND Discussion}

The block diagram of the integrated photovoltaic/wind turbine system, and the power controllers are shown in Fig. 2. The major inputs for the proposed PV model were solar irradiation, PV panel temperature and PV manufacturing data sheet information's. In this study, Astronergy CHSM6610P PV panel is taken as example. The Astronergy CHSM6610P key specification is listed in Table I.

Table I

Astronergy CHSM6610P specifications $\left(1 \mathrm{~kW} / \mathrm{m}^{2}, 25^{\circ} \mathrm{C}\right)$

\begin{tabular}{ll}
\hline Parameter & Value \\
\hline Maximum power $\left(P_{m}\right)$ & $225(\mathrm{~W})$ \\
Open circuit voltage $\left(V_{o c}\right)$ & $36.88(\mathrm{~V})$ \\
Voltage at $P_{m}\left(V_{a m p}\right)$ & $29.76(\mathrm{~V})$ \\
Short circuit current $\left(I_{s c}\right)$ & $8.27(\mathrm{~A})$ \\
Current at $P_{m}\left(I_{a m p}\right)$ & $7.55(\mathrm{~A})$ \\
Temp coefficient for $P_{m}$ & $-0.46\left(\% /{ }^{\circ} \mathrm{C}\right)$ \\
Temp coefficient for $V_{o c}$ & $-0.129\left(\mathrm{~V} /{ }^{\circ} \mathrm{C}\right)$ \\
Temp coefficient for $I_{s c}$ & $+0.052\left(\% /{ }^{\circ} \mathrm{C}\right)$ \\
No. of cells and connections & 60 in series \\
\hline
\end{tabular}

The I-V and P-V output characteristics for the PV model are shown in Fig.12. The output power and current of PV module depend on the solar irradiance and temperature, and cell's terminal operating voltage as well. It was found from Fig. 12(a) and 12(b) that with increased solar irradiance there 
is an increase in both the maximum power output and the short circuit current. On the other hand, we observe from Fig. 12(c) and $12(\mathrm{~d})$ that with an increase in the cell temperature, the maximum power output decreases whilst the short circuit current increases.

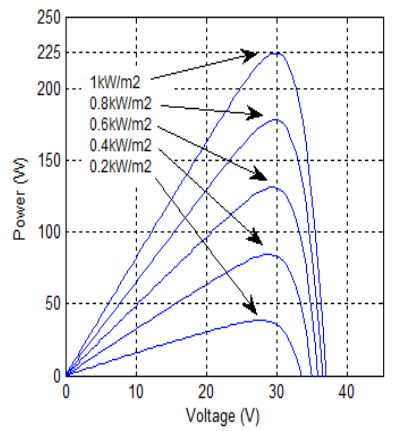

(a)

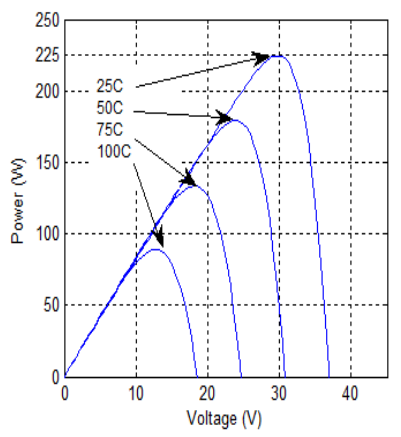

(c)

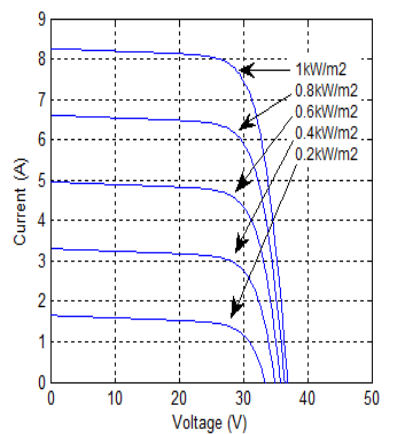

(b)

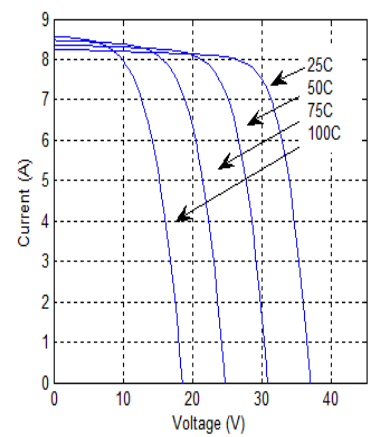

(d)
Fig. 12. I-V and P-V output characteristics (a - b) with different $G(\mathrm{c}-\mathrm{d})$ with different $T_{c}$

The parameters of the wind turbine induction generator are given in Table II.

Table II

Wind Turbine Induction generator parameters

\begin{tabular}{ll}
\hline Parameter & Value \\
\hline Turbine data & $9(\mathrm{~m} / \mathrm{s})$ \\
Base wind speed $\left(\mathrm{w}_{\text {base }}\right)$ & 1 (p.u.) \\
Maximum power at $\mathrm{W}_{\text {base }}\left(k_{p}\right)$ & {$[0.5176,116,0.4,5,21,0.0068]$} \\
Coefficient $\left(\mathrm{c}_{1}-\mathrm{c}_{6}\right)$ & 0.48 (p.u.) for $\left[\beta=0^{\circ}, \lambda=8.1\right]$ \\
Nominal performance coefficient & \\
Generator data & Squirrel cage \\
Rotor type & $200(\mathrm{HP})$ \\
Nominal power $\left(P_{\text {mechanic }}\right)$ & $460(\mathrm{~V})$ \\
Nominal voltage $($ line-to-line) & $60(\mathrm{~Hz})$ \\
Nominal frequency & $1785(\mathrm{rpm})$ \\
Nominal revolutions per minute & 0.01282 (p.u.) \\
Stator resistance & 0.05051 (p.u.) \\
Stator inductance & 0.00702 (p.u.) \\
Rotor resistance & 0.05051 (p.u.) \\
Rotor inductance & 6.77 (p.u) \\
Magnetizing inductance & 0.3096 (s) \\
Inertia constant & 0.0114 (p.u.) \\
Friction factor & 2 \\
Pairs of poles & \\
\hline
\end{tabular}

The generator speed (rpm) and the generator power (p.u.) characteristics for the WT model are shown in Fig. 13 corresponding to various wind speed values. The output power of WT depends on the wind speed and generator speed. As depicted in Fig.13, wind speed is the most influential factor on the amount of power produced by the wind turbine. Because the power in the wind is a cubic function of wind speed, changes in speed produce a profound effect on power.

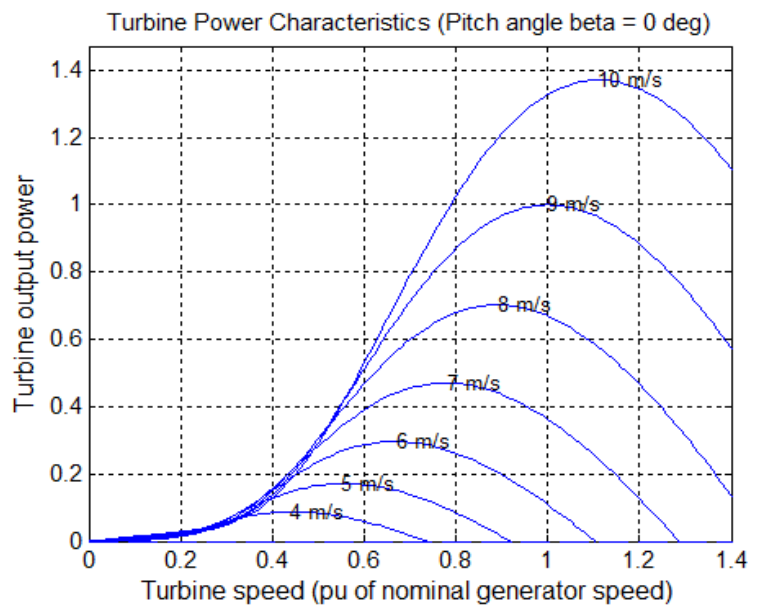

Fig. 13. Wind turbine characteristics

The parameters of the boost type dc/dc converter located at the output of the PV system are given in Table III.

The parameters of the double-bridge rectifier are given in Table IV.

Table III $\mathrm{dc} / \mathrm{dc}$ converter model parameters

\begin{tabular}{ll}
\hline Parameter & Value \\
\hline Input port series resistance & 0.5 \\
Switching loss current & 0.03 \\
Capacitance & $200(\mu \mathrm{F})$ \\
Initial capacitor voltage & $400(\mathrm{~V})$ \\
\hline
\end{tabular}

Table IV

Double-bridge rectifier model parameters

\begin{tabular}{ll}
\hline Parameter & Value \\
\hline Pulse width of synchronized 12-pulse generator & $80\left(^{\circ}\right)$ \\
Proportional gain of PI voltage control system & 2 \\
Integral gain of PI voltage control system & 20 \\
Snubber resistance of one thyristor & $2(\mathrm{k} \Omega)$ \\
Snubber capacitance of one thyristor & $0.1(\mu \mathrm{F})$ \\
Internal resistance of one thyristor & $1(\mathrm{~m} \Omega)$ \\
Filter inductance & $66(\mathrm{mH})$ \\
Filter capacitance & $3300(\mu \mathrm{F})$ \\
Reference voltage & $400(\mathrm{~V})$ \\
\hline
\end{tabular}

Finally, Table $\mathrm{V}$ shows the parameters of the input transformer used in the double-bridge rectifier.

Table V

Transformer parameters

\begin{tabular}{ll}
\hline Parameter & Value \\
\hline Nominal power & $120(\mathrm{~kW})$ \\
$\begin{array}{l}\text { Nominal frequency } \\
\text { Input winding parameters }\end{array}$ & $60(\mathrm{~Hz})$ \\
$\begin{array}{l}\text { (Yg) [V1 R1 L1] } \\
\text { Output winding parameters }\end{array}$ & {$[460(\mathrm{~V}) 0.00025$ (p.u.) 0 (p.u.)] } \\
$\begin{array}{l}\text { (Y) [V2 R2 L2] } \\
\begin{array}{l}\text { Output winding parameters } \\
\text { (Delta) [V3 R3 L3] }\end{array}\end{array}$ & {$[230(\mathrm{~V}) 0.00025$ (p.u.) 0.0024 (p.u.)] } \\
$\begin{array}{l}\text { Magnetization resistance } \\
\text { Magnetization inductance }\end{array}$ & 368.62 (p.u.) \\
\hline
\end{tabular}




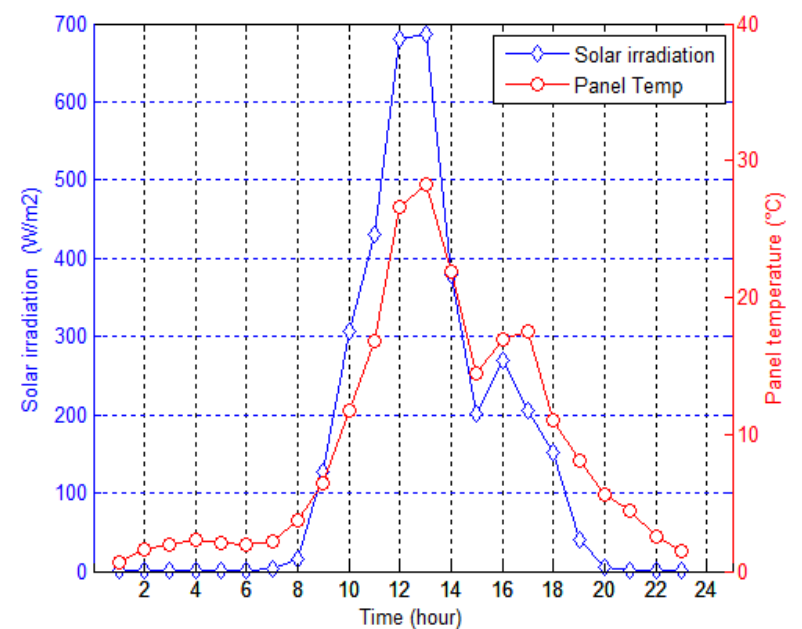

Fig. 14(a) Solar radiation and panel temp profiles used for system simulation

During the simulation process, the aim was to observe the proposed model behavior over a long time period, including day and night cases. The solar radiation and wind speed profiles are used to test the performance of the proposed hybrid system model, as shown in Fig. 14(a) and 14(b). The irradiance, temperature and wind speed data was gathered from a $28.8 \mathrm{~kW}$ grid connected solar power system located in central Manchester. These real-time parameters are used as inputs of the developed PV-wind turbine hybrid model.

Although the photovoltaic voltage fluctuates due to solar radiation variations, the proposed control system of the solar power plant successfully keeps the load voltage stable at $400 \mathrm{~V}$. The output voltage of the dc/dc converter is depicted in Fig.15. The output voltage of the PV panel is depicted in Fig.16.

The objective of the $\mathrm{P} \& \mathrm{O}$ algorithm is to adjust the $\mathrm{dc} / \mathrm{dc}$ control variable $\left(I_{\text {ref }}\right)$, so that the PV array operates at the maximum power point (MPP). And that done, by periodically incrementing or decrementing the PV array operating current $\left(I_{p v}=I_{r e f}\right)$, as shown in Fig. 17.

From Fig. 18, we observe that in the early morning before 8:30am and in the evening after 19:00pm, the solar power is unavailable due to nonexistence of solar radiation. To overcome this deficiency of the PV system, and to increase the amount of power in the early morning, the wind turbine system was added to the solar power plant.

In this study, the stator winding is connected to the grid and the rotor is driven by the wind turbine. The power captured by the wind turbine is converted into electrical power by the induction generator and is transmitted to the grid by the stator winding. As shown in Fig. 14(b), 24-h duration is used for the simulations with a variation in wind speed. This variation in wind speed affects the power produced by the induction generator coupled to the wind turbine as observed in Fig. 19.

From Fig. 20, we observe that although the available power from the wind generator fluctuates due to wind speed variations, the PI controlled firing angle $(\alpha)$ of the doublebridge ac/dc converter successfully maintains the output voltage of the WTIG at $400 \mathrm{~V}$.

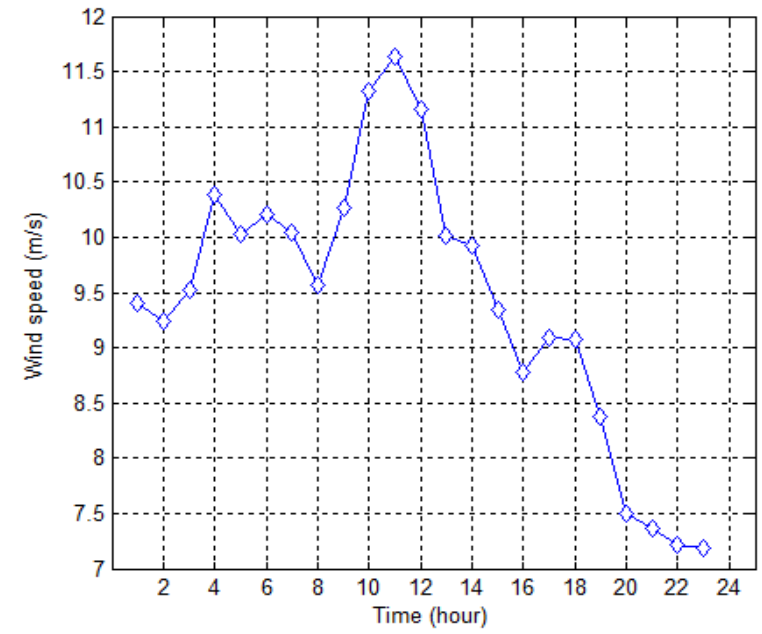

Fig. 14(b) Wind speed profile used for system simulation

Since the voltage of the two dc buses is kept at $400 \mathrm{~V}$, dc/ac inverters are used to deliver the required power to the load side at $60 \mathrm{~Hz}$ frequency and $240 \mathrm{~V}$ line-to-line voltage.

The power delivered to the load side by the PV/WT hybrid topology is illustrated in Fig. 21.

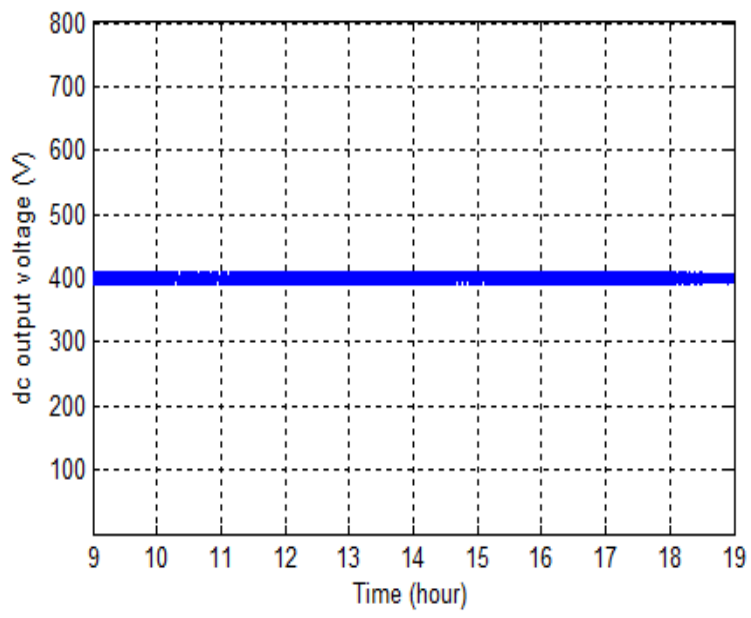

Fig. 15. Output voltage of the $\mathrm{dc} / \mathrm{dc}$ converter

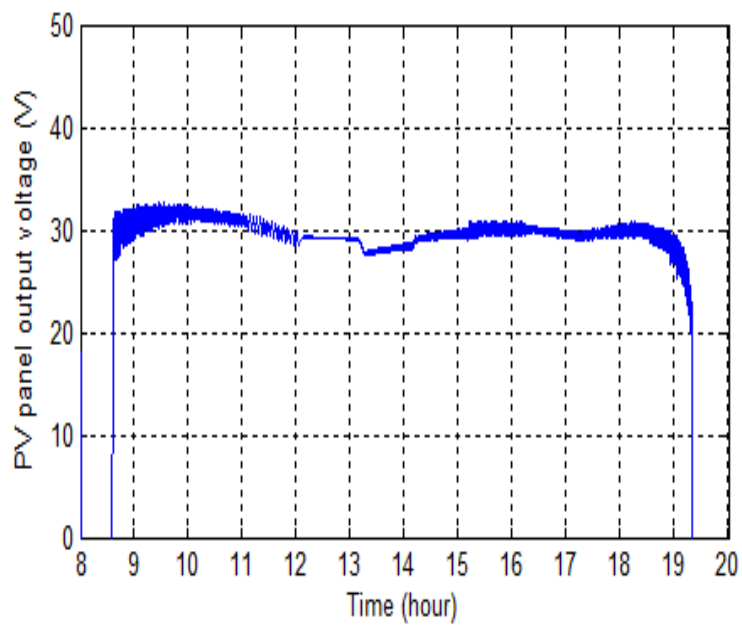

Fig. 16. Output voltage of the PV panel 


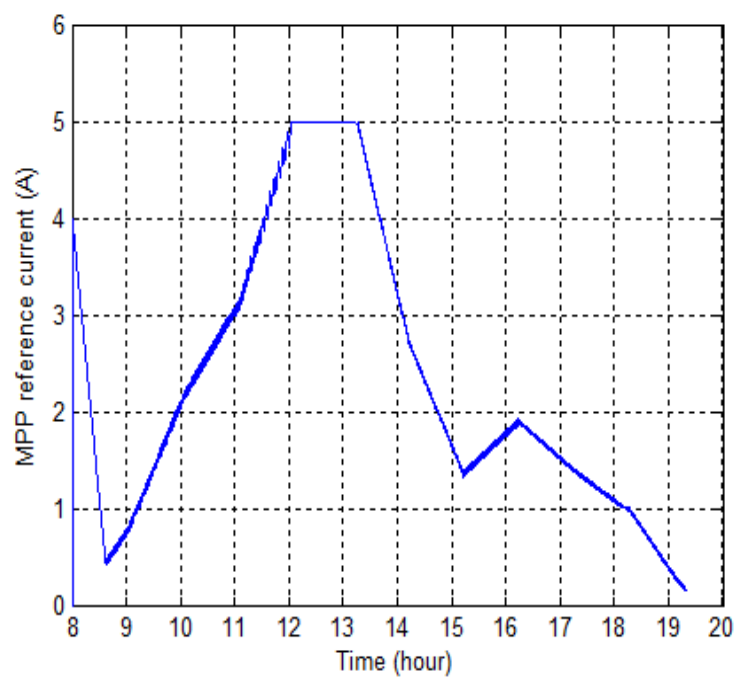

Fig. 17. Output current of the MPPT $\left(I_{r e f}=I_{p v}\right)$

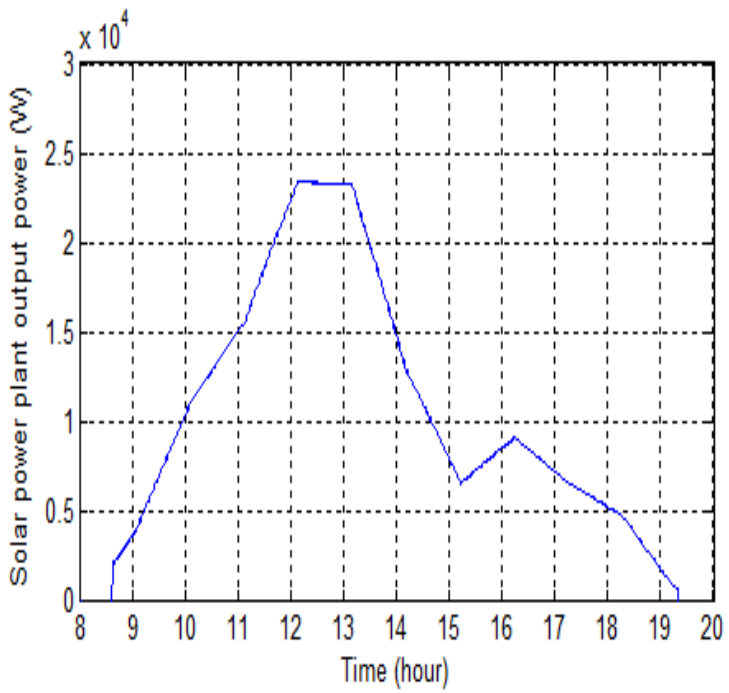

Fig. 18. Total power of the solar power plant (160 Astronergy CHSM6610P PV panel)

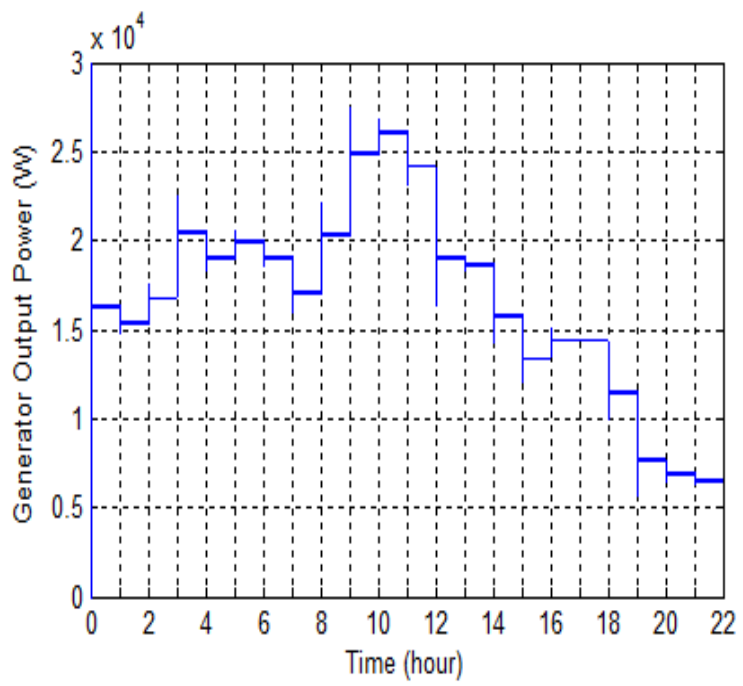

Fig. 19. Power of the generator coupled to the wind turbine

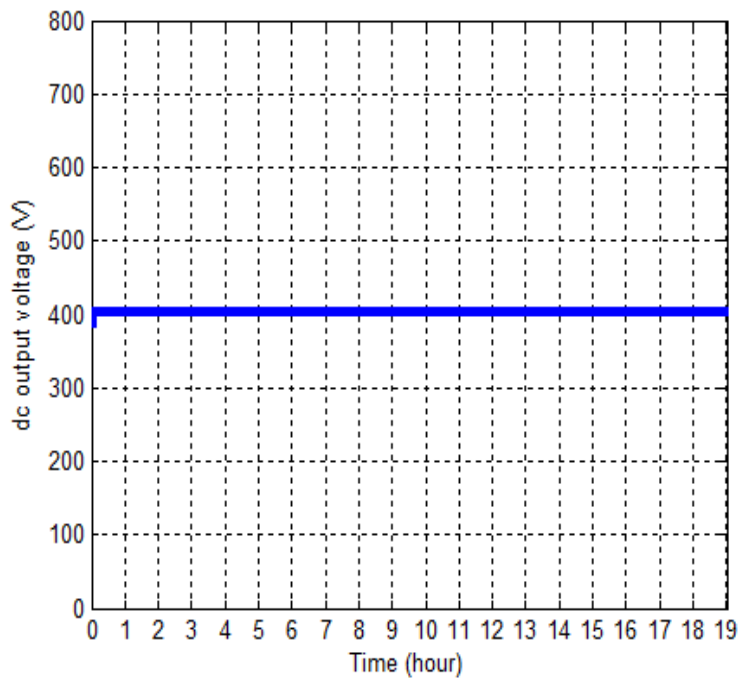

Fig. 20. Output voltage of the double-bridge ac/dc converter

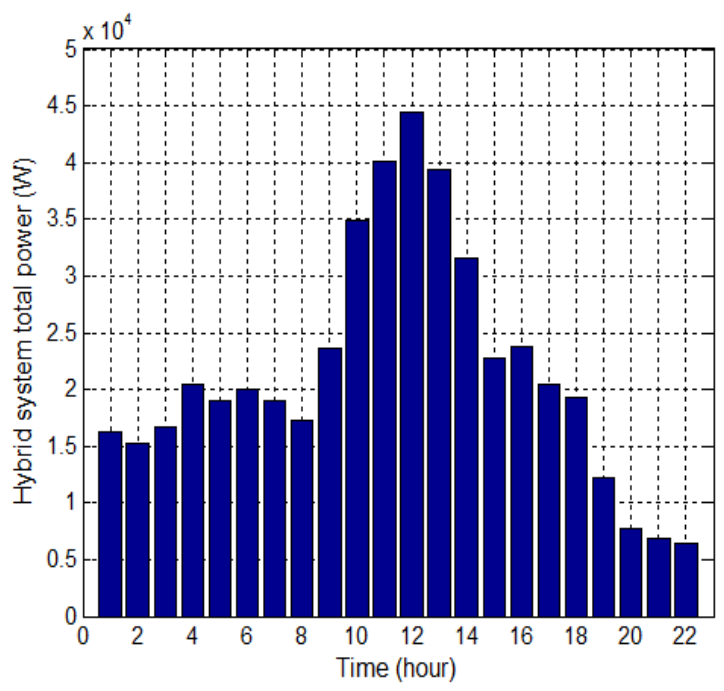

Fig. 21. Power delivered to load side by the hybrid topology

\section{CONCLUSIONS}

In this paper, a novel PV/WT hybrid power system is designed and modelled for smart grid applications. The developed algorithm comprises system components and an appropriate power flow controller. The model has been implemented using the MATLAB/SIMULINK software package, and designed with a dialog box like those used in the SIMULINK block libraries. The available power from the PV system is highly dependent on solar radiation. To overcome this deficiency of the PV system, the PV module was integrated with the wind turbine system. The dynamic behavior of the proposed model is examined under different operating conditions. Solar irradiance, temperature and wind speed data is gathered from a $28.8 \mathrm{~kW}$ grid connected solar power system located in central Manchester. The developed system and its control strategy exhibit excellent performance for the simulation of a complete day. The proposed model offers a proper tool for smart grid performance optimization. 


\section{REFERENCES}

[1]E. Miller, "Smart grids - a smart idea?," Renewable Energy Focus Magazine, vol. 10, pp. 62-67, Sep.-Oct. 2009.

[2]H. Yang, Z. Wei, and L. Chengzh, "Optimal design and technoeconomic analysis of a hybrid solar-wind power generation system," Applied Energy, vol. 86, pp. 163-169, Feb. 2009.

[3]S. Dihrab, and K. Sopian, "Electricity generation of hybrid PV/wind systems in Iraq," Renewable Energy, vol. 35, pp. 1303-1307, Jun. 2010.

[4]J.P. Reichling, and F.A. Kulacki, "Utility scale hybrid wind-solar thermal electrical generation: a case study for Minnesota," Energy, vol. 33, pp.626-638, Apr. 2008.

[5]O. Ekren, B.Y. Ekren, and B. Ozerdem, "Break-even analysis and size optimization of a PV/wind hybrid energy conversion system with battery storage - A case study" Applied Energy, vol.86, pp. 1043-1054, July-August 2009.

[6]S.K. Kim, J.H. Jeon, C.H. Cho, E.S. Kim, and J.B. Ahn, "Modeling and simulation of a grid-connected PV generation system for electromagnetic transient analysis, "Solar Energy, vol.83, pp. 664678, May 2009.

[7]H.L Tsai, "Insolation-oriented model of photovoltaic module using Matlab/Simulink," Solar Energy, vol. 84, pp. 1318-1326, July 2010.

[8]J.A. Gow, and C.D. Manning, "Development of a photovoltaic array model for use in power-electronics simulation studies," IEE Proceedings- Electric Power Applications, vol. 146, pp. 193-199, Mar. 1999.

[9]M.J. Khan, and M.T. Iqbal, "Dynamic modeling and simulation of a small wind fuel cell hybrid energy system," Renewable Energy, vol. 30, pp. 421-439, Mar. 2005.

[10] N. Chayawatto, K. Kirtikara, V. Monyakul, C. Jivacate, and D. Chenvidhya, "DC-AC switching converter modelings of a PV grid-connected system under islanding phenomena," Renewable Energy, vol. 34, pp. 2536-2544, Dec. 2009.

[11] O.C. Onara, M. Uzunoglua, and M.S. Alam, "Dynamic modeling, design and simulation of a wind/fuel cell/ultra-capacitor-based hybrid power generation system, "Journal of Power Sources, vol. 161, pp. 707-722, Oct. 2006.

[12] J.C.H. Phang, D.S.H. Chan, and J.R. Philips, “Accurate analytical method for the extraction of solar cell model parameter," IEEE Electronics Letters, vol. 20, pp.406-408, May 1984.

[13] M.G. Villalva, J.R. Gazoli, and E.R. Filho, "Comprehensive approach to modeling and simulation of photovoltaic arrays," IEEE Transactions on Power Electronics, vol. 24, pp 1198 - 1208, May 2009.

[14] H. De Battista, R.J. Mantz, F. Garelli, "Power conditioning for a wind-hydrogen energy system," Journal of Power Sources, vol. 155, pp. 478-486, Apr. 2006.

[15] E. Muljadi, C.P. Butterfield, "Pitch-controlled variable-speed wind turbine generation," IEEE Trans. Industry Appl., vol. 37, pp. 240246, Jan.-Feb. 2001.

[16] Z. Lubosny, Wind Turbine Operation in Electric Power Systems, Berlin: Springer, chap. 5, 2003.

\section{BIOGRAPHIES}

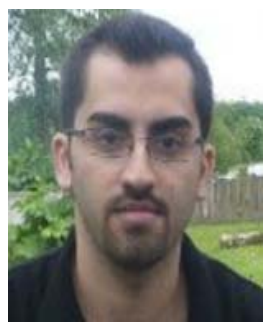

Emad Natsheh (BSc, MSc (Dist)) was born in Jerusalem in 1985. He holds a Master's degree in Computer and Network Technology (CNT) from MMU and a B.A. in Computer Engineering from Najah University. Prior to entering the $\mathrm{PhD}$ program at MMU, Emad worked for one year with the World Bank as IT Specialist /Web Programmer to modify the quality of e-learning using SCORM standard. His current research interests include alternative energy sources, fuel cells, power system modelling, energy management and control algorithms based on artificial intelligence.

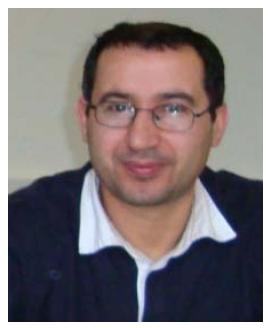

Alhussein Albarbar (BSc, MSc (Hons), $\mathrm{PhD}$ MIET, CEng) has a considerable industrial working experience and more than 10 years experience in teaching engineering. He is a chartered engineer and currently working with Manchester Metropolitan University as a Senior Lecturer in Engineering. He has supervised a series of industrially sponsored Master's and Doctoral research projects. $\mathrm{Dr}$ Albarbar has widely published; over 50 technical papers in refereed journals and international conference proceedings. His current research activities include renewable power systems, smart sensing, intelligent monitoring algorithms and electromechanical plants diagnostics.

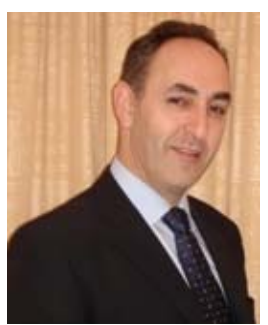

Javad Yazdani. (BEng, MEng (Hons), MSc, PGCE, PhD) MIEEE, MIEEE, FIFL. Javad is a Senior Lecturer in Nuclear Engineering and has considerable industrial experience and expertise in nuclear related Mechatronics Engineering, Digital Communication Systems and Digital Signal Processing and its Application in Communication Systems. Javad has been researching and teaching in engineering for almost 17 years. Currently he is the academic lead in the field of Smart Grid Technology and PLC working in the new Centre of Excellence "uclan NUCLEAR" within the School of Computing, Engineering and Physical Science at the University of Central Lancashire. He is currently supervising number of MSc and PhD students and has published many technical papers in the refereed journals and international conference proceedings. His current research focus is Smart Grid related to utilizing PLC as a hybrid communication medium for smart and intelligent sensor/control and renewable energy engineering and energy management. Javad is also exploring the role of Smart Grid and Grid vulnerability with respect to Nuclear Security and Safeguards. 